Original Contribution

\title{
ANTIOXIDANT ACTIVITY AND EVALUATION ESSENTIAL OIL OF ACHILLEA WILHELMSII FROM IRAN
}

\author{
M. Kazemi* \\ Department of Horticultural Science, Faculty of Agricultural Science and Natural Resources, \\ Science and Research Branch, Islamic Azad University, Tehran, Iran
}

\begin{abstract}
This study reports the essential oil composition and antioxidant activity of the essential oil extract of aerial parts of Achillea Wilhelmsii. GC/MS analysis identified thirty compounds representing 94.48\% of the oil. The main components comprising $86.99 \%$ of the oil were $\alpha$-thujene $(6.11 \%)$, $\alpha$-pinene $(5.11 \%)$, sabinene (5.23\%), p-cymene (7\%), 1,8-cineole (6\%), linalool(10\%), camphor $(8.43 \%)$, thymol $(18.98 \%)$ and carvacrol (20.13\%). The samples were screened for their antioxidant activities using 2,2-diphenyl-1picrylhydrazyl (DPPH) radical assay methods. Thymol $(13.0 \pm 0.1 \mu \mathrm{g} / \mathrm{ml})$ and carvacrol $(15 \pm 0.0 \mu \mathrm{g} / \mathrm{ml})$ showed appreciable antioxidant activity in DPPH test.
\end{abstract}

Key words: Achillea Wilhelmsii, Chemical composition, Antioxidant activity, DPPH assays

\section{INTRODUCTION}

Reactive oxygen and nitrogen species, ROS/RNS are continuously produced in the human body and they are controlled by endogenous enzymes (superoxide dismutase, glutathione peroxidase, catalase). The ROS hydrogen peroxide caused lipid peroxidation and DNA oxidative damage in cells (1). Antioxidants are substances that inhibit or delay the oxidation processes. Therefore, they are able to protect the human body, foods, and drugs from oxidative damages $(2,3)$. Hence, strong restrictions have been mandated for their application and there is also a trend to the development of more effective and safer antioxidants, especially from natural origins (3, 4). Since ancient times, herbs and spices in different types of food to improve flavours are well known for their antioxidant capacities (5). For example, various herbs and spices essential oils (such as clove, oregano, rosemary, sage, and lavender) have been reported to exhibit strong antioxidant and lipid

*Correspondence to: Mohsen Kazemi, Department of Horticultural Science, Faculty of Agricultural Science and Natural Resources, Science and Research Branch, Islamic Azad University, Tehran, Iran,E-mail: kazemimohsen85@gmail protection properties (6). In recent decades, the essential oils and various extracts of plants have been of great interest as they have been the sources of natural products. In order to prolong the storage stability of foods, synthetic antioxidants are used for industrial processing.

Achillea Wilhelmsii C. Koch (A. Wilhelmsii) is one of the widespread species of Achillea in Iran. Numerous studies have been conducted to evaluate the pharmacologic effects of the essential oil as well as different extracts of this herb. It is shown that this plant has antimicrobial, antitumoral, antihypertensive and vagolitic properties $(7,8)$. However studies to support antioxidant properties of the volatile oil have not yet been reported. The main objectives of the present study were to evaluate the antioxidant properties of the essential oil from Achillea Wilhelmsii aerial parts and to find out which compounds contribute to the effects.

\section{MATERIALS AND METHODS Plant material and oil isolation}

The plant materials were collected from the mountains in the city of Ilam-Iran in 2012- 2013. The Achillea Wilhelmsii aerial parts such as stem, flowers and leaves were ground and the 
resulting powder was subjected to hydrodistillation for 3 hours in an all glass

Clevenger-type apparatus according to the method recommended by the European Pharmacopoeia (9). The obtained essential oils were dried over anhydrous sodium sulphate and after filtration, stored at $+4{ }^{\circ} \mathrm{C}$ until tested and analysed.

\section{Essential oil analysis}

The GC/MS analyses were executed on a Hewlett-Packard 5973N gas chromatograph equipped with a column HP-5MS (30 m length $\times$ $0.25 \mathrm{~mm}$ i.d., film thickness $0.25 \mathrm{~lm}$ ) coupled with a Hewlett-Packard 5973N mass spectrometer. The column temperature was programmed at $50{ }^{\circ} \mathrm{C}$ as an initial temperature, holding for $6 \mathrm{~min}$, with $3{ }^{\circ} \mathrm{C}$ increases per minute to the temperature of $240{ }^{\circ} \mathrm{C}$, followed by a temperature enhancement of $15^{\circ} \mathrm{C}$ per minute up to $300{ }^{\circ} \mathrm{C}$, holding at the mentioned temperature for $3 \mathrm{~min}$. Injector port temperature was $290{ }^{\circ} \mathrm{C}$ and helium used as carrier gas at a flow rate 1.5 $\mathrm{ml} / \mathrm{min}$. Ionization voltage of mass spectrometer in the EI-mode was equal to $70 \mathrm{eV}$ and ionization source temperature was $250{ }^{\circ} \mathrm{C}$. Linear retention indices for all components were determined by coinjection of the samples with a solution containing homologous series of $\mathrm{C} 8$ C22 n-alkanes and comparing them and their mass spectra with those of authentic samples or with available library data of the GC/MS system (WILEY 2001 data software) and Adams libraries spectra (10).

\section{Antioxidant activity}

The efficacy of the essential oils to scavenge 2,20-diphenyl-1-picrylhydrazyl (DPPH) radicals was evaluated using a spectrophotometry method $(11,12)$. On basis of bleaching of the bluish-red or purple colour of DPPH solution as a reagent. Briefly, a $50 \mathrm{ll}$ volume of various dilutions of each samples was mixed with $5 \mathrm{ml}$ of $0.004 \%$ methanol solutions of DPPH followed by $30 \mathrm{~min}$ incubation at ambient temperature. Thereafter, the sample absorbance was recorded against control at $517 \mathrm{~nm}$. The inhibition percentages were measured using Eq. (1). The antioxidants activity of the test samples in concentration providing $50 \%$ inhibition, were considered as IC50 $(\mathrm{lg} / \mathrm{ml})$.

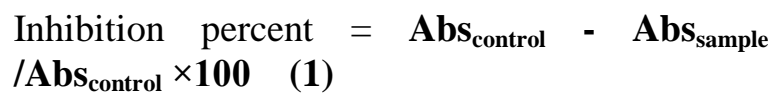

Butylhydroxyanisole (BHA) and ascorbic acid were used as positive controls. All experiments were repeated three times and the average results and standard deviations calculated.

\section{Statistical analysis}

The quantitative data of major components of oil were statistically examined by one-way analysis of variance (ANOVA), and significant differences among groups were subsequently analyzed by Duncan's multiple range test $(\mathrm{P}<$ $0.05)$. Correlation and regression coefficients were performed using Statistical Package for the Social Sciences (SPSS).

\section{RESULTS AND DISCUSSION Chemical composition of the essential oil} Ground aerial parts of the plant were subjected to hydrodistillation using a clevenger-type apparatus. GC/MS analysis resulted in the identification of thirty compounds representing $94.48 \%$ of the oils (Table 1). The plant essential oil was consisted mostly of monoterpenes with both non-oxygenated and oxygenated alkene structures. $\alpha$-thujene $(6.11 \%), \alpha$-pinene $(5.11 \%)$, camphen $(0.43 \%)$, sabinene $(5.23 \%), \beta$-pinene $(1 \%)$, p-cymene $(7 \%), \quad 1,8$-cineole $(6 \%), \gamma$ terpinene $(1 \%), \alpha$-pinene oxide $(0.34 \%)$, linalool (10\%), thujol $(0.2 \%)$, cis-thujone $(0.11)$, $\alpha$-campholenal $(0.43 \%)$,camphor $(8.43 \%)$, 4terpineneol $(0.11 \%)$, myrtenol $(0.2 \%)$, farganol $(0.1 \%)$, piperitone $(0.34 \%)$, p-cymen-7-ol $(0.4 \%)$, thymol $(18.98 \%), 3$-verbenyl acetate $(0.3 \%)$, carvacrol $(20.13 \%)$, linalool isobutyrate (1\%), $\alpha$-copaene $(0.45 \%)$, linalool butyrate $(0.12 \%)$, Isobornyl n-butyrate $(0.1 \%)$, dehadecalactone (0.19), 1-phenyl heptan-3-one $(0.1 \%), 1,10$-decanediol $(0.43 \%)$ and elemol $(0.14 \%)$ were the main components comprising $94.48 \%$ of the oil. The reports on the chemical composition of the essential oils of the plants of genus Achillea are scant in the literature. 1,8cineol was found in the essential oil of $A$. wilhelmsii as major components $(13,14)$ and camphor $(2.2 \%)$ and borneol $(6.4 \%)$ was reported as one of the main compounds in the oil of A. tenuifolia (15). Carvacrol (25.1\%), linalool $(11.5 \%)$ and 1,8 cineol $(10.3 \%)$ were also found in considerable amounts in the oil of $A$. Wilhelmsii collected from Iran (16). Finally, camphor, 1,8 cineol, linalool and $\alpha$-terpineol were reported as major compounds in the essential oil of $A$. Wilhelmsii (17). 
Table 1. Chemical composition of Achillea wilhelmsii volatile oil constituents.

\begin{tabular}{cccccc} 
Compound & $\%$ & RI & Compound & $\%$ & RI \\
\hline$\alpha$-Thujene & 6.11 & 926 & Myrtenol & 0.2 & 1192 \\
$\alpha$-Pinene & 5.11 & 931 & Farganol & 0.1 & 1210 \\
Camphen & 0.43 & 940 & Piperitone & 0.34 & 1248 \\
Sabinene & 5.23 & 960 & $P$-Cymen-7-ol & 0.4 & 1280 \\
$\beta$-Pinene & 1 & 973 & Thymol & 18.98 & 1290 \\
$P$-cymene & 7 & 1025 & 3-Verbenyl acetate & 0.3 & 1295 \\
1,8-Cineole & 6 & 1031 & Carvacrol & 20.13 & 1308 \\
$\gamma$-Terpinene & 1 & 1060 & Linalool isobutyrate & 1 & 1370 \\
$\alpha$-Pinene oxide & 0.34 & 1095 & $\alpha$-Copaene & 0.45 & 1380 \\
Linalool & 10 & 1090 & Linalool butyrate & 0.12 & 1410 \\
Thujol & 0.2 & 1125 & Isobornyl n-butyrate & 0.1 & 1460 \\
Cis-Thujone & 0.11 & 1103 & Deha-decalactone & 0.19 & 1500 \\
$\alpha-$ Campholenal & 0.43 & 1123 & 1-Phenyl heptan-3-one & 0.1 & 1520 \\
Camphor & 8.43 & 1140 & 1,10-Decanediol & 0.43 & 1541 \\
4-Terpineneol & 0.11 & 1174 & Elemol & 0.14 & 1550 \\
\hline Total & \multicolumn{7}{c}{ 94.48 }
\end{tabular}

\section{Antioxidant activity}

Numerous and diverse techniques are available to evaluate the antioxidant activities of specific compounds or complex mixtures such as EOs; therefore, in the present study, assays was conducted in order to evaluate in vitro antioxidant properties of our EOs samples: scavenging activity on DPPH radicals. In the DPPH assay, the radical scavenging capacity of the tested EOs increased in a concentration dependent manner. The lower $\mathrm{IC}_{50}$ value indicates a stronger ability of the extract to act as a DPPH scavenger while the higher $\mathrm{IC}_{50}$ value indicates a lower scavenging activity of the scavengers as more scavengers were required to achieve $50 \%$ scavenging reaction. The results presented in Table 2 revealed that Achillea wilhelmsii essential oil and its main constituents exhibited a remarkable activity. In particular, thymol showed clearly a higher activity (IC50 = $13.05 \pm 0.1 \mu \mathrm{g} / \mathrm{ml}$ ) followed by Achillea wilhelmsii essential oil $(17 \pm 1.1 \mu \mathrm{g} / \mathrm{ml})$ and carvacrol $(15 \pm 0.0 \mu \mathrm{g} / \mathrm{ml})$. $\alpha$-pinene $(22 \pm 1.0$ $\mu \mathrm{g} / \mathrm{ml})$, camphor $(20 \pm 0.5 \mu \mathrm{g} / \mathrm{ml}), \alpha$-thujene $(21 \pm 0.1 \mu \mathrm{g} / \mathrm{ml})$, sabinene $(20 \pm 0.4 \mu \mathrm{g} / \mathrm{ml}), p$ cymene $(20 \pm 0.3 \mu \mathrm{g} / \mathrm{ml}), 1,8$-cineole $(21 \pm 0.2$ $\mu \mathrm{g} / \mathrm{ml})$ and linalool $(20 \pm 0.1 \mu \mathrm{g} / \mathrm{ml})$ were inactive (Table 2), despite previous reports of their in vitro antioxidant activities (18). BHT and ascorbic acid as positive controls were exhibited $\mathrm{IC}_{50}$ values equal to $14.01 \pm 0.1 \mu \mathrm{g} / \mathrm{ml}$ and $7 \pm 0.0 \mu \mathrm{g} / \mathrm{ml}$, respectively. Antioxidant activity exhibited by tested EOs justifies traditional uses of Achillea wilhelmsii herbs. The observed antioxidant potential should be addressed to the phenolic oil constituents (19), while the oil chemo-protective efficacy against oxidative stress-mediated disorders ismainly due to its free radical scavenging and metal chelating properties. The antioxidant activities of these volatiles in cellular assays have not been previously reported and the results could be explained by the fact that in vitro tests do not take the physiological conditions of the cell, bioavailability of the antioxidant molecule, as well as general cellular metabolism into account (20). Carvacrol and thymol have been reported to contribute to the in vitro antioxidant activity of essential oil $(21,22)$. In conclusion, our results show that Achillea wilhelmsii oil and two of its main compounds, thymol and carvacrol, are sources of antioxidant for the food, cosmetic and pharmaceutical industries. 
Table 2. DPPH radical scavenging activity of Achillea wilhelmsii aerial parts essential oil and its main constituents. Butylhydroxyanisole (BHA) and ascorbic acid were used as positive controls.

\begin{tabular}{cc}
\hline Tested compounds & IC50 $(\mu \mathrm{g} / \mathrm{ml})$ \\
\hline Achillea wilhelmsii essential oil & $17 \pm 1.1 \mu \mathrm{g} / \mathrm{ml}$ \\
Thymol & $13.05 \pm 0.1 \mu \mathrm{g} / \mathrm{ml}$ \\
Carvacrol & $15 \pm 0.0 \mu \mathrm{g} / \mathrm{ml}$ \\
$\alpha$-Thujene & $21 \pm 0.1 \mu \mathrm{g} / \mathrm{ml}$ \\
$\alpha$-Pinene & $22 \pm 1.0 \mu \mathrm{g} / \mathrm{ml}$ \\
Sabinene & $20 \pm 0.4 \mu \mathrm{g} / \mathrm{ml}$ \\
P-Cymene & $20 \pm 0.3 \mu \mathrm{g} / \mathrm{ml}$ \\
1,8-Cineole & $21 \pm 0.2 \mu \mathrm{g} / \mathrm{ml}$ \\
Linalool & $20 \pm 0.1 \mu \mathrm{g} / \mathrm{ml}$ \\
Camphor & $20 \pm 0.5 \mu \mathrm{g} / \mathrm{ml}$ \\
BHA & $14.01 \pm 0.1 \mu \mathrm{g} / \mathrm{ml}$ \\
AA & $7 \pm 0.0 \mu \mathrm{g} / \mathrm{ml}$ \\
\hline
\end{tabular}

\section{CONCLUSION}

Plants are able to produce different secondary metabolites qualitatively and quantitatively in different geographical areas. Also production of crude drugs is subjected to the variation of the climate, to crop disease, to varying methods of collection and drying which influence quality, and to the inherent variation of active constituents arising from plants of the same species, but having different genetic characteristics. Thus, it may be suggested that other researchers work on Achillea Wilhelmsii collected in different areas.

\section{REFERENCES}

1. Pervaiz, S., and Clement, M.V., Superoxide anion: oncogenic reactive oxygen species? Int. J. Biochem. Cell. Biol, Vol. 39, pp.1297-1304, 2007.

2. Hsouna, A.B., Trigui, M., Culioli, G., Blache, Y., and Jaoua, S., Antioxidant constituents from Lawsonia inermis leaves: Isolation, structure elucidation and antioxidative capacity. Food Chem, Vol. 125:,pp. 193-200, 2011.

3. Aktumsek, A., Zengin, G., Guler, G.O., Cakmak, Y.S., and Duran, A., Antioxidant potentials and anticholinesterase activities of methanolic and aqueous extracts of three endemic Centaurea L. species. Food Chem. Toxicol, Vol. 55, pp.290-296, 2013.
4. Viuda-Martos, M., Ruiz Navajas, Y., Sánchez Zapata, E., Fernández-López, J., and PérezÁlvarez, JA., Antioxidant activity of essential oils of five spice plants widely used in a Mediterranean diet. Flavour Frag. J, Vol.25, pp. 13-19, 2010.

5. Madsen, H. L., and Bertelsen, G., Spices as antioxidants. Trends in Food Science and Technology, Vol. 6, pp.271-277,1995.

6. Adorjan, B., and Buchbauer, G., Biological properties of essential oils: an updated review. Flavour Frag. J, Vol.25, pp. 407426,2010.

7. Tosun, F., Kizilay, C.A., Sener, B., Vural, M., and Palittapongarnpim, P., Antimycobacterial screening of some Turkish plants. J Ethnopharmacol, Vol. 95, pp.273-275,2004.

8. Niazmand, S., Khooshnood, E., and Derakhshan, M., Effects of Achillea wilhelmsii on rat's gastric acid output at basal, vagotomized, and vagal-stimulated conditions. Pharmacogn Mag. Vol. 6, pp.282-285,2010.

9. European Pharmacopoeia.Vol. 3, Maisonneuve S. A., Sainte-Ruffine, 1975.

10. Adams, R.P., Identification of Essential Oils Components by Gas Chromatography/Quadra pole Mass Spectroscopy. Carol Stream, IL, Allured. 61- 367, 2001. 
11. Cuendet, M., Hostettmann, K., Potterat, O., and Dyatmiko, W., Iridoid glucosides with free radical scavenging properties from Fagraea blumei. Helvetica Chimica Acta, Vol. 80(4), pp.1144-1152,1997.

12. Kirby, A.J., and Schmidt, R.J., The antioxidant activity of Chinese herbs for eczema and of placebo herbs-I. Journal of Ethnopharmacology, Vol. 56(2), pp.103108,1997..

13. Brunke, E.J., Hammerschmidt, F.J., and Aboutabl, E.A., In: Brunke, E. J., ed. Progress in Essential Oil Research. New York: Walter de Gruyter. p. 85-92,1986.

14. Azadbakht, M., Morteza-semnani, K., and Khansari, N.,The essential oils composition of Achillea wilhelmsii C. Koch. leaves and flowers. J. of Medicinal Plants, Vol. 2,pp. 55-59,2003.

15. Aghjani, Z., Masoudi, S.H., and Rustaiyan, A., Composition of essential oil from flowers of Achillea tenuifolia lam. J. Essent. Oil Res, Vol. 12,pp.723-724,2000.

16. Javidnia, K., Miri, R., and Sadeghpour, H., Composition of the Volatile Oil of Achillea Wilhelmsii C. Koch from Iran. Daru, Vol. 12, pp.63-66,2004.

17. Kordali, S., Cakir, A., Aytas, T., Akcin, E., Mete, A., and Akcin, T., Antifungal and
KAZEMI $M$.

herbicidal properties of essential oils and nhexane extracts of Achillea gypsicola HubMor. and Achillea biebersteinii Afan (Asteraceae). Ind Crop Prod, Vol. 29,pp.562-570,2009.

18. Ruberto, G., and Baratta, M.T., Antioxidant activity of selected essential oil components in two lipid model systems. Food Chemistry, Vol. 69,pp.167-174,2000.

19. Hazzit, M., Baaliouamer, A., Verissimo, A.R., Faleiro, M.L., and Miguel, M.G., Chemical composition and biological activities of Algerian Thymus oils. Food Chem, Vol. 116,pp.714-721,2009.

20. Girard-Lalancette, K., Pichette, A., and Legault, J., Sensitive cell-based assay using DCFH oxidation for the determination of pro- and antioxidant properties of compounds and mixtures: analysis of fruit and vegetable juices. Food Chemistry, Vol. 115, pp.720-726, 2009.

21. Piccaglia, R., Marotti, M., Giovanelli, E., Deans, S., and Eaglesham, E.,Antibacterial and antioxidant properties of Mediterranean aromatic plants. Ind. Crop. Prod, Vol. 2,pp. 47-50, 1993

22. Burits, M., and Bucar, Antioxidant activity of Nigella sativa essential oil. Phytother. Res, Vol. 14, pp. 323-328, 2000. 